\title{
Jurnal KOPASTA
}

Jurnal KOPASTA, 3(2), 2016

\section{Pengaruh Penerapan Metode Ceramah Plus dengan Metode Resitasi Terhadap Motivasi Belajar Mahasiswa Bimbingan Konseling Universitas Riau Kepulauan Batam}

\author{
Junierissa Marpaung, M.Psi ${ }^{\star a}$ \\ ${ }^{a}$ Division of Guidance and Counseling, Riau Kepulauan University, Batam, Indonesia.
}

\begin{abstract}
Abstrak
Berdasarkan survei awal, ditemukan banyak mahasiswa yang memiliki motivasi belajar yang rendah, hal ini terlihat dari perilaku yang ditampilkan oleh mahasiswa tesebut, seperti pasif pada saat proses pembelajaran, nilai ujian dan tugas yang rendah, pada saat diberikan tugas lebih memilih melihat dari teman daripada berusaha mencari sendiri yang mungkin disebabkan oleh metode pengajaran dosen yang tidak sesuai dengan kebutuhan mahasiswa dan menimbulkan kejenuhan.. Tujuan penelitian ini adalah untuk membantu meningkatkan motivasi belajar mahasiswa.

Berdasarkan hasil penelitian ditemukan: 1) Terdapat peningkatan motivasi belajar sesudah diberi metode ceramah plus dengan tingkat perbedaan $Z$ sebesar -3,411 dengan taraf signifikansi 0,001. 2) Terdapat peningkatan motivasi belajar mahasiswa sesudah diberi metode resitasi dengan tingkat perbedaan $\mathrm{Z}$ sebesar $-3,410$ dengan signifikan 0,001. 3) Tidak terdapat perbedaan motivasi belajar antara kelompok dengan metode ceramah plus dan kelompok dengan metode resitasi dengan tingkat perbedaan $\mathrm{Z}$ sebesar 1.470 dengan signifikansi 0,142.

Sehingga dapat disimpulkan bahwa metode ceramah plus dan metode resitasi memiliki kontribusi yang lebih baik dalam meningkatkan motivasi belajar mahasiswa. Namun, tidak ada perbedaan antara metode ceramah plus dan metode resitasi dalam meningkatkan motivasi belajar mahasiswa. Berdasarkan temuan di atas dapat disimpulkan bahwa motivasi belajar siswa dapat ditingkatkan melalui metode pengajaran ceramah plus dan metode pengajaran resitasi. Penelitian ini menunjukkan pentingnya melaksanakan metode pengajaranyang sesuai dengan kebutuhan mahasiswa sehingga dapat meningkatkan hasil belajar mahasiswa.
\end{abstract}

\section{Kata kunci: metode ceramah plus, metode resitasi, motivasi belajar}

\begin{abstract}
Based on the initial survey, found many students who have the motivation to learn is low, it can be seen from the behavior displayed by the student proficiency level, such as passive during the learning process, test scores and the task is low, when given the task prefer viewed from a friend rather than trying find your own that may be caused by the lecturer teaching methods that do not fit the needs of students and lead to saturation. The purpose of this study is to help improve student learning motivation. Based on the results of the study found: 1) There is an increased motivation to learn after given a lecture plus the level difference $\mathrm{Z}$ of -3.411 with a significance level of 0.001. 2) There is an increased motivation to learn the student after the given method of recitation with a level difference of -3.410 with a significant $Z$ 0,001. 3) There is no difference between the groups with learning motivation plus lecture and group recitation method to the level difference $\mathrm{Z}$ of 1.470 with 0.142 significance. So it can be concluded that the method plus lecture and recitation method had good contribution on improving student learning motivation. However, there is no difference between plus lecturing and recitation methods to improve students' learning motivation. Based on the findings it can be concluded that students' motivation can be enhanced through the plus lecturing teaching methods and recitation teaching methods. This study shows the importance of carrying out the neccesary or suitable method due to students' needs in order to improve student outcomes.
\end{abstract}

Keywords: lecturing plus method, resitation method learning motivation

\section{PENDAHULUAN}

\section{Latar Belakang Masalah}

Sadirman (2009) motivasi didefinisikan sebagai kondisi internal yang membangkitkan kita untuk bertindak, mendorong kita mencapai tujuan tertentu, dan membuat kita tetap tertarik dalam 
kegiatan tertentu, motivasi dapat diartikan sebagai dorongan internal dan eksternal dalam diri seseorang yang diindikasikan dengan adanya, hasrat dan minat, dorongan dan kebutuhan, harapan dan cita-cita, penghargaan dan penghormatan. Motivasi adalah sesuatu apa yang membuat seseorang bertindak. Sadirman (2009), motivasi seseorang dapat ditimbulkan dan tumbuh berkembang melalui dirinya sendiri-intrinsik dan dari lingkungan-ekstrinsik. Motivasi intrinsik bermakna sebagai keinginan dari diri sendiri untuk bertindak tanpa adanya rangsangan dari luar. Motivasi intrinsik akan lebih menguntungkan dan memberikan keajegan dalam belajar. Motivasi ekstrinsik dijabarkan sebagai motivasi yang datang dari luar individu dan tidak dapat dikendalikan oleh individu tersebut. Dengan pengertian di atas maka dapat dikaitkan dengan motivasi belajar siswa dimana dalam penelitian ini membahas tentang motivasi belajar yang harus diterapkan di dalam lingkungan perguruan tinggi bertujuan agar mahasiswa dapat termotivasi dalam belajar.

Kegiatan belajar mengajar melibatkan beberapa komponen, yaitu peserta didik, guru/dosen (pendidik), tujuan pembelajaran, metode mengajar, dan media. Selain itu, peranan seorang pendidik/pengajar juga tidak kalah penting, yaitu bagaimana seseorang pengajar bisa mengembangkan potensi kegiatan pengajarannya dan potensi siswanya, dalam rangka mentransfer ilmu pengetahuan, agar tujuan pembelajaran dapat dicapai secara optimal. Metode mengajar adalah suatu cara yang harus dilalui dalam mengajar, metode mengajar ini mempengaruhi motivasi belajar mahasiswa. Jika metode megajar guru/dosen kurang baik dalam artian guru/dosen kurang menguasai materi-materi kurang persiapan, guru/dosen tidak menggunakan variasi dalam menyampaikan pelajaran alias monoton, semua ini bisa malas belajar, bosan, mengantuk dan akibatnya mahasiswa tidak berhasil dalam menguasai materi perkuliahan.

Ada beberapa metode mengajar yang dapat dipraktekkan pada saat mengajar, yaitu: Metode Ceramah (Preaching Method), Metode Diskusi (Discussion Method), Metode Demonstrasi (Demonstration Method), Metode Ceramah Plus yang terbagi dalam beberapa macam, yaitu Metode Ceramah Plus Tanya Jawab dan Tugas (CPTT), Metode Ceramah Plus Diskusi dan Tugas (CPDT), dan Metode Ceramah Plus Demonstrasi dan Latihan (CPDL), Metode Resitasi, Metode Percobaan (Experimental Method), Metode Karya Wisata, Metode Latihan Keterampilan (Drill Method), Metode Mengajar Beregu (Team Teaching Method), Metode Mengajar Sesama Teman (Peer Teaching Method), Metode Pemecahan Masalah (Problem Solving Method), Metode Perancangan (Project Method), Metode Bagian (Teileren Method), Metode Global (Ganze Method), Metode Discovery, dan Metode Inquiry.

Dalam penelitian ini, peneliti menggunakan metode mengajar ceramah plus diskusi dan tugas (CPDT) dan metode resitasi. Metode ceramah plus adalah metode mengajar yang menggunakan lebih dari satu metode, yakni metode ceramah gabung dengan metode lainnya. Metode ceramah plus memiliki jenis-jenisnya dan salah satunya adalah metode ceramah plus 
diskusi dan tugas (CPDT). Metode ini dilakukan secara tertib sesuai dengan urutan pengkombinasiannya, yaitu: (1). Tenaga pengajar menguraikan materi pengajarannya; (2). Kemudian mengadakan diskusi;dan (3). Akhirnya Pemberian Tugas. Metode Resitasi (Recitation Method) adalah suatu metode mengajar dimana mahasiswa diharuskan membuat resume dengan kalimat sendiri (dalam http://re-searchengines.com/art05-65.html).

Berdasarkan hasil observasi peneliti, peneliti melihat masih banyak mahasiswa yang suka melamun pada saat perkuliahan berlangsung, lebih memilih untuk melakukan aktivitas yang tidak berhubungan dengan proses pembelajaran. Pada saat aktivitas tanya jawab, mahasiswa lebih memilih untuk diam padahal masih banyak yang tidak paham tentang materi perkuliahan yang telah disampaikan oleh dosen. Mahasiswa juga terlihat kurang semangat pada saat perkuliahan berlangsung. Berdasarkan latar belakang masalah di atas, peneliti tertarik untuk melakukan penelitian dengan judul "Pengaruh Penerapan Metode Ceramah Plus dengan Metode Resitasi Terhadap Motivasi Belajar Mahasiswa Bimbingan Konseling Universitas Riau Kepulauan Batam".

\section{Tujuan Penelitian}

Adapun tujuan dalam penelitian ini adalah:

1. Untuk mengetahui bagaimana motivasi belajar mahasiswa bimbingan konseling sebelum dan sesudah diberikan metode ceramah plus.

2. Untuk mengetahui bagaimana motivasi belajar mahasiswa bimbingan konseling sebelum dan sesudah diberikan metode resitasi.

3. Untuk mengetahui apakah terdapat pengaruh motivasi belajar mahasiswa bimbingan konseling sebelum dan sesudah diberikan metode ceramah plus.

4. Untuk mengetahui apakah terdapat pengaruh motivasi belajar mahasiswa bimbingan konseling sebelum dan sesudah diberikan metode resitasi.

5. Untuk mengetahui apakah terdapat perbedaan antara metode ceramah plus dan metode resitasi terhadap motivasi belajar mahasiswa bimbingan konseling.

\section{TINJAUAN PUSTAKA}

\section{Motivasi Belajar}

Menurut Sardiman (2012) motivasi belajar adalah seluruh penggerak di dalam diri siswa yang menimbulkan kegiatan belajar, yang menjamin kelangsungan dari kegiatan belajar dan memberikan arah pada kegiatan belajar sehingga tujuan yang dikehendaki oleh siswa dapat tercapai. Menurut Frandsen (dalam Sardiman, 2012) ada beberapa aspek yang memotivasi belajar 
seseorang, yaitu: Adanya sifat ingin tahu dan ingin menyelidiki dunia yang lebih luas, adanya sifat yang kreatif yang ada pada manusia dan keinginan untuk selalu maju, adanya keinginan untuk mendapatkan simpati dari orang tua, guru, dan teman-teman, adanya keinginan untuk memperbaiki kegagalan yang lalu dengan usaha yang baru, baik dengan kooperasi maupun dengan kompetisi, adanya keinginan untuk mendapatkan rasa aman bila menguasai pelajaran, dan adanya ganjaran atau hukuman sebagai akhir daripada belajar.

Menurut Sardiman (2012) bahwa motivasi memiliki ciri-ciri sebagai berikut:

a. Tekun menghadapi tugas (dapat bekerja terus-menerus dalam waktu yang lama, tidak pernah berhenti sebelum selesai).

b. Ulet menghadapi kesulitan (tidak lekas putus asa). Tidak memerlukan dorongan dari luar untuk berprestasi setinggi mungkin (tidak cepat puas dengan prestasi yang dicapainya).

c. Menunjukkan minat terhadap bermacam-macam masalah.

d. Lebih senang bekerja mandiri.

e. Cepat bosan pada tugas-tugas yang rutin (hal-hal yang bersifat mekanis, berulang-ulang begitu saja, sehingga kurang kreatif).

f. Dapat mempertahankan pendapatnya (kalau sudah yakin akan sesuatu).

g. Tidak mudah melepaskan hal yang diyakini itu.

h. Senang mencari dan memecahkan masalah soal-soal.

Menurut Darsono (dalam Dwi, 2005) mengemukakan faktor yang mempengaruhi motivasi belajar adalah sebagai berikut: cita-cita/aspirasi, kemampuan belajar, kondisi siswa, kondisi lingkungan, unsur-unsur dinamis dalam belajar. Menurut Sardiman (2012) ada 3 fungsi motivasi, yaitu:

a. Mendorong manusia untuk berbuat, jadi sebagai penggerak atau motor yang melepaskan energi. Motivasi dalam hal ini merupakan motor penggerak dari setiap kegiatan yang akan dikerjakan.

b. Menentukan arah perbuatan, yakni ke arah tujuan yang hendak dicapai. Dengan demikian motivasi dapat memberikan arah dan kegiatan yang harus dikerjakan sesuai dengan rumusan tujuannya.

c. Menyeleksi perbuatan, yakni menentukan perbuatan-perbuatan apa yang harus dikerjakan yang serasi guna mencapai tujuan, dengan menyisihkan perbuatan-perbuatan yang tidak bermanfaat bagi tujuan tersebut. Misalnya, saja seorang siswa yang akanmenghadapi ujian dengan harapan dapat lulus, tentu akan melakukan kegiatan belajar dan tidak akan menghabiskan waktunya untuk bermain kartu, membaca komik, sebab tidak serasi dengan tujuan.

Menurut Sardiman (2012) ada beberapa bentuk dan cara untuk menumbuhkan motivasi dalam kegiatan belajar di sekolah: memberi angka, hadiah, saingan/kompetisi, ego-involvement, 
memberi ulangan, mengetahui hasil, pujian, hukuman, hasrat untuk belajar, minat, dan tujuan yang diakui.

\section{Metode Ceramah Plus Diskusi dan Tugas (CPDT)}

Metode Ceramah Plus Diskusi dan Tugas (CPDT) adalah metode ini dilakukan secara tertib dengan urutan pengkombinasiannya, yaitu pertama guru menguraikan materi pelajaran, kemudian mengadakan diskusi, dan akhirnya memberi tugas (dalam Asep Kusman, 2013).

\section{Metode Resitasi}

Metode Resitasi adalah suatu metode mengajar dimana siswa diharuskan membuat resume dengan kalimat sendiri (dalam Asep Kusman, 2013).

Kelebihan dan Kelemahan Metode Resitasi

a. Kelebihan Metode Resitasi

Kelebihan metode resitasi adalah sebagai berikut (dalam Asep Kusman,2013):

1) Pengetahuan yang anak didik peroleh dari hasil belajar sendiri akan dapat diingat lebih lama.

2) Anak didik berkesempatan memupuk perkembangan dan keberanian mengambil inisiatif, tanggung jawab dan berdiri sendiri.

b. Kelemahan Metode Resitasi

Kelemahan metode resitasi adalah sebagai berikut (dalam Asep Kusman,2013):

1) Terkadang anak didik melakukan penipuan dimana anak didik hanya meniru hasil pekerjaan temannya tanpa mau bersusah payah mengerjakan sendiri.

2) Terkadang tugas dikerjakan oleh orang lain tanpa pengawasan.

3) Sukar memberikan tugas yang memenuhi perbedaan individual.

\section{Hipotesis}

1. $\mathrm{H}_{\mathrm{a} 1}$ : Terdapat motivasi belajar mahasiswa FKIP Universitas Riau Kepulauan Batam sebelum diberi metode ceramah plus dan sesudah diberi ceramah plus.

$\mathrm{H}_{\mathrm{o1}}$ : Tidak Terdapat perbedaan motivasi belajar mahasiswa FKIP Universitas Riau Kepulauan Batam sebelum diberi metode ceramah plus dan sesudah diberi metode ceramah plus.

2. $\mathrm{Ha}_{2}$ : Terdapat motivasi belajar mahasiswa FKIP Universitas Riau Kepulauan Batam sebelum diberi metode resitasi dan sesudah diberi metode resitasi.

$\mathrm{Ho}_{2}$ : Tidak terdapat perbedaan motivasi belajar mahasiswa FKIP Universitas Riau Kepulauan Batam sebelum diberi metode ceramah plus dan sesudah diberi metode resitasi.

3. На ${ }_{3}$ : Terdapat perbedaan motivasi belajar antara kelompok dengan metode ceramah plus dan kelompok dengan metode resitasi setelah diberi perlakuan. 
$\mathrm{Ho}_{3}$ : Tidak terdapat perbedaan motivasi belajar antara kelompok dengan metode ceramah plus dan kelompok dengan metode resitasi setelah diberi perlakuan.

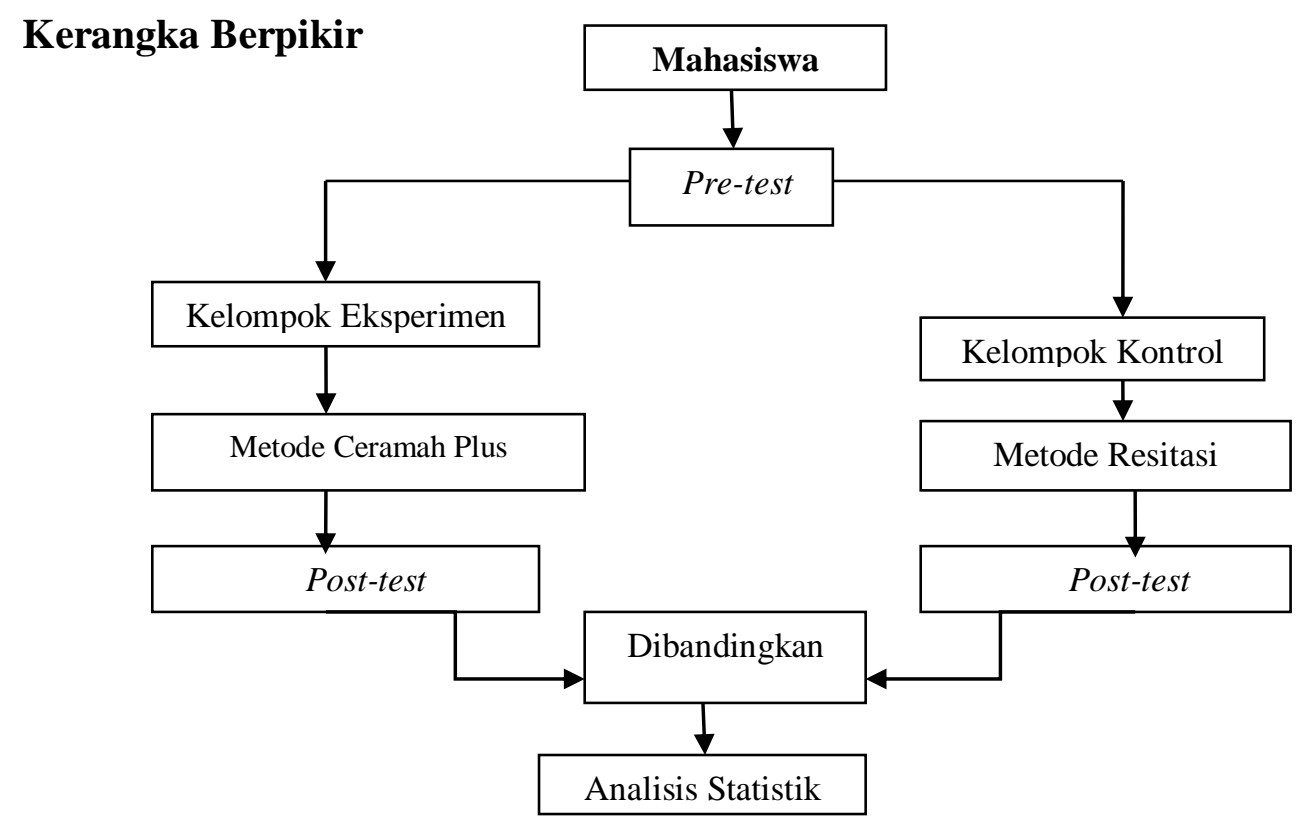

\section{METODE PENELITIAN}

Jenis penelitian ini adalah Quasi Exsperimental Design atau dapat dikatakan sebagai metode eksperimen semu. Quasi experiment design adalah eksperimen yang memiliki perlakuan (treatments), pengukuran-pengukuran dampak dan unit-unit eksperimen namun tidak menggunakan penempatan secara acak. Dengan desain Nonequivalent control group design (Sugiyono, 2013). Sampel adalah bagian atau wakil dari populasi yang mencerminkan keadaan populasi (Arikunto, 2006). Sesuai dengan masalah yang diteliti, Sampel yang dipilih haruslah representative sehingga menggambarkan keseluruhan karakteristik dari suatu populasi, dimana sampel diambil kelas yang mewakili dari populasi yang ada di Fakultas Keguruan dan Ilmu Pendidikan Universitas Riau Kepulauan Batam semester 3. Dalam pengambilan sampel peneliti mengunakan teknik cluster sampling sebanyak 15 orang mahasiswa. Variabel penelitian dalam penelitian ini terdiri dari dua, yaitu: variable bebas (metode ceramah plus dan metode resitasi) dan variable terikat (motivasi belajar). Teknik pengumpulan data dalam penelitian ini menggunakan angket yang berisi pernyataan dengan menggunakan skala likert. Sedangkat teknik analisis data dalam penelitian ini menggunakan analisis Wilcoxon signed ranks test.

\section{HASIL PENELITIAN}

\section{Deskripsi Pretest dan Posttest Motivasi Belajar dengan Metode Ceramah Plus}

Adapun data hasil pretest yang dilakukan pada kelas eksperimen dapat disajikan pada tabel di bawah ini : 
Tabel 1. Skor Pretest dan Posttest dengan Metode Ceramah Plus

\begin{tabular}{|c|l|l|l|l|l|l|}
\hline \multirow{2}{*}{ No } & \multicolumn{3}{|c|}{ Pretest } & \multicolumn{3}{c|}{ Posttest } \\
\cline { 2 - 7 } & $\begin{array}{c}\text { Nama } \\
\text { Inisial }\end{array}$ & Skor & Kategori & $\begin{array}{c}\text { Nama } \\
\text { Inisial }\end{array}$ & Skor & Kategori \\
\hline 1. & Rahasia & 27 & Rendah & Rahasia & 42 & Sedang \\
\hline 2. & Rahasia & 27 & Rendah & Rahasia & 57 & Sedang \\
\hline 3. & Rahasia & 36 & Rendah & Rahasia & 59 & Sedang \\
\hline 4. & Rahasia & 44 & Rendah & Rahasia & 60 & Sedang \\
\hline 5. & Rahasia & 54 & Sedang & Rahasia & 64 & Sedang \\
\hline 6. & Rahasia & 35 & Rendah & Rahasia & 60 & Sedang \\
\hline 7. & Rahasia & 40 & Rendah & Rahasia & 65 & Sedang \\
\hline 8. & Rahasia & 48 & Sedang & Rahasia & 62 & Sedang \\
\hline 9. & Rahasia & 51 & Sedang & Rahasia & 61 & Sedang \\
\hline 10. & Rahasia & 53 & Sedang & Rahasia & 60 & Sedang \\
\hline 11. & Rahasia & 36 & Rendah & Rahasia & 60 & Sedang \\
\hline 12. & Rahasia & 38 & Rendah & Rahasia & 63 & Sedang \\
\hline 13. & Rahasia & 37 & Rendah & Rahasia & 58 & Sedang \\
\hline 14. & Rahasia & 43 & Sedang & Rahasia & 70 & Tinggi \\
\hline 15. & Rahasia & 32 & Rendah & Rahasia & 49 & Sedang \\
\hline 16. & JUMLAH & $\mathbf{6 0 1}$ & & & $\mathbf{8 9 0}$ & \\
\hline
\end{tabular}

Adapun hasil data tersebut dapat kita jelaskan dan dapat diperinci pada tabel di bawah ini:

Tabel 2. Hasil Frekuensi Pretest dan Posttest dengan Metode Ceramah Plus

\begin{tabular}{|l|l|l|l|l|l|}
\hline \multirow{2}{*}{ No } & \multicolumn{3}{|c|}{ Pretest } & \multicolumn{2}{c|}{ Posttest } \\
\cline { 2 - 6 } & \multicolumn{1}{|c|}{ Kategori } & Frekuensi & Persentase (\%) & Frekuensi & Persentase (\%) \\
\hline 1 & Sangat rendah & 0 & $0 \%$ & 0 & $0 \%$ \\
\hline 2 & Rendah & 10 & $66,67 \%$ & 0 & $0 \%$ \\
\hline 3 & Sedang & 5 & $33,33 \%$ & 14 & $93,33 \%$ \\
\hline 4 & Tinggi & 0 & $0 \%$ & 1 & $6,67 \%$ \\
\hline 5 & Sangat tinggi & 0 & $0 \%$ & 0 & $0 \%$ \\
\hline & JUMLAH & $\mathbf{4 6}$ & $\mathbf{1 0 0 \%}$ & $\mathbf{4 6}$ & $\mathbf{1 0 0 \%}$ \\
\hline
\end{tabular}

Untuk lebih jelasnya dapat kita lihat pada garafik di bawah ini:

Pretest

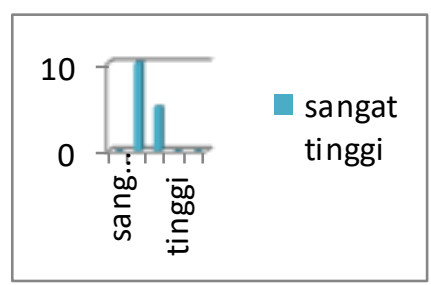

Posttest

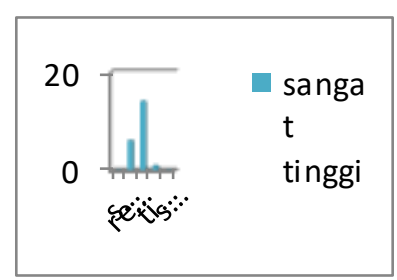

Gambar 1. Grafik Skor Pretest dan Posttest dengan Metode Ceramah Plus

Deskripsi Pretest dan Posttest Motivasi Belajar Mahasiswa dengan Metode Resitasi

Adapun data hasil pretest yang dilakukan pada kelas eksperimen dapat disajikan pada tabel di bawah ini :

Tabel 3. Skor Pretest dan Postest dengan Metode Resitasi

\begin{tabular}{|r|c|c|l|c|c|c|}
\hline \multirow{2}{*}{ No } & \multicolumn{3}{|c|}{ Pretest } & \multicolumn{3}{c|}{ Posttest } \\
\cline { 2 - 7 } & Nama & Skor & Kategori & Nama & Skor & Kategori \\
\hline 1. & Rahasia & 27 & Rendah & Rahasia & 66 & Sedang \\
\hline
\end{tabular}




\begin{tabular}{|c|c|c|c|c|c|c|}
\hline 2. & Rahasia & 27 & Rendah & Rahasia & 57 & Sedang \\
\hline 3. & Rahasia & 36 & Rendah & Rahasia & 64 & Sedang \\
\hline 4. & Rahasia & 44 & Rendah & Rahasia & 60 & Sedang \\
\hline 5. & Rahasia & 54 & Sedang & Rahasia & 72 & Tinggi \\
\hline 6. & Rahasia & 35 & Rendah & Rahasia & 56 & Sedang \\
\hline 7. & Rahasia & 40 & Rendah & Rahasia & 61 & Sedang \\
\hline 8. & Rahasia & 48 & Sedang & Rahasia & 68 & Tinggi \\
\hline 9. & Rahasia & 51 & Sedang & Rahasia & 64 & Sedang \\
\hline 10. & Rahasia & 53 & Sedang & Rahasia & 58 & Sedang \\
\hline 11. & Rahasia & 36 & Rendah & Rahasia & 61 & Sedang \\
\hline 12. & Rahasia & 38 & Rendah & Rahasia & 58 & Sedang \\
\hline 13. & Rahasia & 37 & Rendah & Rahasia & 65 & Sedang \\
\hline 14. & Rahasia & 43 & Sedang & Rahasia & 66 & Sedang \\
\hline 15. & Rahasia & 32 & Rendah & Rahasia & 58 & Sedang \\
\hline JUMLA & $\mathbf{A H}$ & & & & 934 & \\
\hline
\end{tabular}

Lebih jelasnya dapat kita lihat pada tabel di bawah ini:

Tabel 4. Hasil Frekuensi Pretest dan Postest dengan Metode Resitasi

\begin{tabular}{|l|l|c|c|c|c|}
\hline \multirow{2}{*}{ No } & \multicolumn{3}{|c|}{ Pretest } & \multicolumn{2}{c|}{ Postest } \\
\cline { 2 - 6 } & Kategori & Frekuensi & Persentase \% & Frekuensi & Persentase \% \\
\hline 1 & Sangat rendah & 0 & $0 \%$ & 0 & $0 \%$ \\
\hline 2 & Rendah & 10 & $66,67 \%$ & 0 & $0 \%$ \\
\hline 3 & Sedang & 5 & $33,33 \%$ & 13 & $86,67 \%$ \\
\hline 4 & Tinggi & 0 & $0 \%$ & 2 & $13,33 \%$ \\
\hline 5 & Sangat tinggi & 0 & $0 \%$ & 0 & $0 \%$ \\
\hline & & $\mathbf{4 6}$ & $\mathbf{1 0 0 \%}$ & $\mathbf{4 6}$ & $\mathbf{1 0 0 \%}$ \\
\hline
\end{tabular}

Data tersebut dapat kita buat grafik seperti di bawah ini:

Pretest

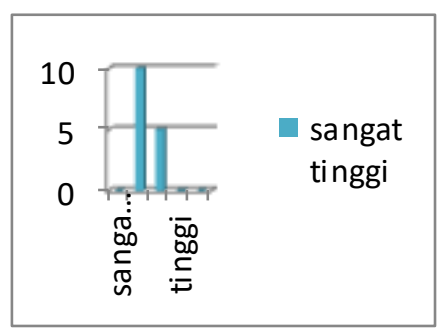

Posttest

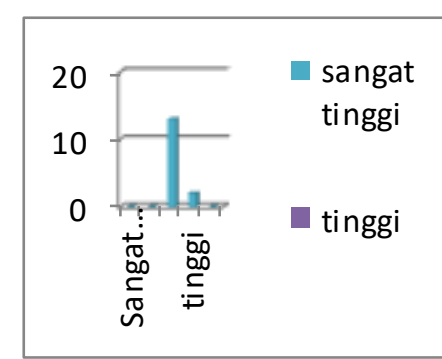

Gambar 2. Grafik Skor Pretest dan Postest dengan Metode Resitasi

\section{Distribusi Posttest dengan Metode Ceramah Plus dan Posttest dengan Metode Resitasi}

Adapun hasil posttest baik kelompok dengan metode ceramah plus maupun kelompok dengan metode resitasi dapat disajikan pada tabel di bawah ini:

Tabel 5. Hasil Posttest dengan Metode Ceramah Plus dan Kelompok dengan Metode Resitasi

\begin{tabular}{|c|c|c|l|c|c|c|}
\hline \multirow{2}{*}{ No } & \multicolumn{2}{|c|}{ Kelompok Metode Ceramah Plus } & \multicolumn{3}{c|}{ Kelompok Metode Resitasi } \\
\cline { 2 - 7 } & Nama & Skor & \multicolumn{1}{|c|}{ Kategori } & Nama & Skor & Kategori \\
\hline 1. & Rahasia & 42 & Sedang & Rahasia & 66 & Sedang \\
\hline 2. & Rahasia & 57 & Sedang & Rahasia & 57 & Sedang \\
\hline 3. & Rahasia & 59 & Sedang & Rahasia & 64 & Sedang \\
\hline
\end{tabular}




\begin{tabular}{|c|l|l|l|l|c|c|}
\hline 4. & Rahasia & 60 & Sedang & Rahasia & 60 & Sedang \\
\hline 5. & Rahasia & 64 & Sedang & Rahasia & 72 & Tinggi \\
\hline 6. & Rahasia & 60 & Sedang & Rahasia & 56 & Sedang \\
\hline 7. & Rahasia & 65 & Sedang & Rahasia & 61 & Sedang \\
\hline 8. & Rahasia & 62 & Sedang & Rahasia & 68 & Tinggi \\
\hline 9. & Rahasia & 61 & Sedang & Rahasia & 64 & Sedang \\
\hline 10. & Rahasia & 60 & Sedang & Rahasia & 58 & Sedang \\
\hline 11. & Rahasia & 60 & Sedang & Rahasia & 61 & Sedang \\
\hline 12. & Rahasia & 63 & Sedang & Rahasia & 58 & Sedang \\
\hline 13. & Rahasia & 58 & Sedang & Rahasia & 65 & Sedang \\
\hline 14. & Rahasia & 70 & Tinggi & Rahasia & 66 & Sedang \\
\hline 15. & Rahasia & 49 & Sedang & Rahasia & 58 & Sedang \\
\hline \multicolumn{2}{|l|}{ Rata-rata } & $\mathbf{5 9 , 3 3}$ & Rata-rata & $\mathbf{6 2 , 2 7}$ & \\
\hline
\end{tabular}

Berdasarkan tabel di atas maka dapat diketahui bahwa terdapat perbedaan yang cukup signifikan antara kelompok dengan metode ceramah plus dan kelompok dengan metode resitasi. Untuk skor rata-rata posttest kelompok dengan resitasi lebih besar dari rata-rata kelompok dengan metode ceramah plus yaitu 62,27 dibanding 59,33. Selain itu kelompok dengan metode ceramah plus terdapat kenaikan skor motivasi belajar sebanyak 15 mahasiswa (keseluruhan mengalami kenaikan skor). Dari jumlah skor rata-rata mereka terdapat kenaikan yang signifikan sehingga motivasi belaajr mahasiswa pada kategori sedang dan tinggi. Sedangkan pada kelompok dengan metode resitasi terdapat kenaikan dan skor motivasi belajar yakni 15 mahasiswa (keseluruhan mahasiswa mengalami kenaikan skor). Adapun data perbedaan kelompok dengan metode ceramah plus dan dengan metode resitasi dapat kita perhatikan pada tabel di bawah ini:

Tabel 6. Distribusi Hasil Frekuensi Persentase Posttest dengan Metode Ceramah Plus dan Posttest dengan Metode Resitasi.

\begin{tabular}{|l|l|l|l|l|l|}
\hline No & \multicolumn{1}{|c|}{ Kategori } & $\begin{array}{c}\text { Posttest } \\
\text { Metode Ceramah Plus }\end{array}$ & Persentase & $\begin{array}{c}\text { Posttest } \\
\text { Metode Resitasi }\end{array}$ & Persentase \\
\hline 1 & Sangat Rendah & 0 & $0 \%$ & 0 & $0 \%$ \\
\hline 2 & Rendah & 0 & $0 \%$ & 0 & $0 \%$ \\
\hline 3 & Sedang & 14 & $93,33 \%$ & 13 & $86,67 \%$ \\
\hline 4 & Tinggi & 1 & $6,67 \%$ & 2 & $13,33 \%$ \\
\hline 5 & Sangat Tinggi & 0 & $0 \%$ & 0 & $0 \%$ \\
\hline & TOTAL & $\mathbf{1 5}$ & $\mathbf{1 0 0 \%}$ & $\mathbf{1 5}$ & $\mathbf{1 0 0 \%}$ \\
\hline
\end{tabular}

Perbedaan Kategori Posttest Pada Kelompok dengan Metode Ceramah Plus dan Posttest Kelompok dengan Metode Resitasi

Kelompok Metode Ceramah Plus

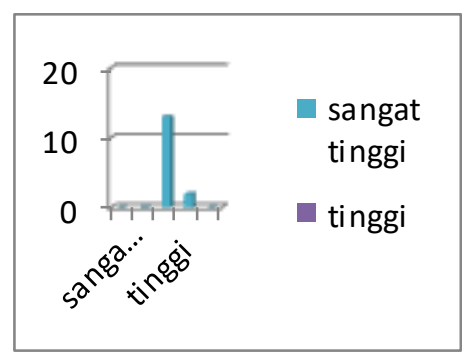

Kelompok Metode Resitasi

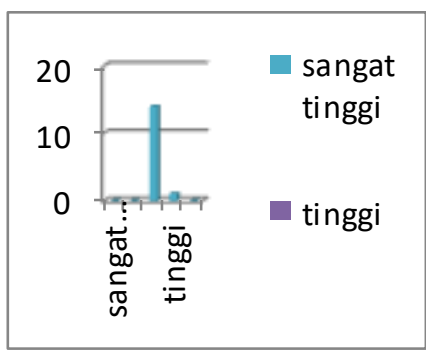

Gambar 3. Grafik Perbedaan Posttest Kelompok dengan Metode Ceramah Plus dan Kelompok dengan Metode Resitasi 
Hipotesis pertama yang diajukan dalam penelitian ini adalah :

"Terdapat perbedaan motivasi belajar mahasiswa di FKIP Universitas Riau Kepulauan Batam sebelum diberi metode ceramah plus dan sesudah diberi metode ceramah plus"

Pengujian hipotesis ini ini dilakukan dengan teknik analisis data mengunakan Wilcoxon Signed Rangk Test melalui SPSS statistics versi 20 for windows. Berdasarkan hal tersebut didapat hasil perhitungan seperti yang terangkum pada tabel di bawah ini. Dapat kita lihat pada tabel di bawah ini:

Tabel 7. Hasil Analisis Wilcoxon Signed Rangk Test Perbedaan Motivasi Belajar Mahasiswa pada Pretest dan Posttest Kelompok dengan Metode Ceramah Plus Test Statistics ${ }^{a}$

\begin{tabular}{|l|r|}
\hline & Prosttest Ceramah Plus - Pretest \\
\hline$Z$ & $-3.411^{\mathrm{b}}$ \\
Asymp. Sig. (2-tailed) & .001 \\
\hline
\end{tabular}

a. Wilcoxon Signed Ranks Test

b. Based on negative ranks.

Berdasarkan tabel di atas dapat dilihat bahwa angka probabilitas Sig. (2-tailed) motivasi belajar mahasiswa pada kelompok dengan metode ceramah plus adalah 0,001 atau probabilitas di bawah alpha $(0,000<0,05)$. Dari hasil tersebut maka Ho ditolak dan Ha diterima. Dengan demikian dapat disimpulkan bahwa terdapat pengaruh yang signifikan motivasi belajar mahasiswa pada kelompok dengan metode ceramah plus sebelum dan sesudah diberikan perlakuan.

Hipotesis pertama yang diajukan dalam penelitian ini adalah :

"Terdapat perbedaan motivasi belajar mahasiswa di FKIP Universitas Riau Kepulauan Batam sebelum diberi metode resitasi dan sesudah diberi metode resitasi"

Pengujian hipotesis ini ini dilakukan dengan teknik analisis data mengunakan Wilcoxon Signed Rangk Test melalui SPSS statistics versi 20 for windows. Berdasarkan hal tersebut didapat hasil perhitungan seperti yang terangkum pada tabel di bawah ini. Dapat kita lihat pada tabel di bawah ini:

Tabel 8. Hasil Analisis Wilcoxon Signed Rangk Test Perbedaan Motivasi Belajar Mahasiswa pada Pretest dan Posttest Kelompok dengan Metode Resitasi Test Statistics ${ }^{\mathrm{a}}$

\begin{tabular}{|l|r|}
\hline & Posttest Resitasi - Pretest \\
\hline Z & $-3.410^{\mathrm{b}}$ \\
Asymp. Sig. (2-tailed) & .001 \\
\hline
\end{tabular}

b. Based on negative ranks.

Berdasarkan tabel di atas dapat dilihat bahwa angka probabilitas Sig. (2-tailed) motivasi belajar mahasiswa pada kelompok dengan metode resitasi adalah 0,001 atau probabilitas di bawah alpha $(0,000<0,05)$. Dari hasil tersebut maka Ho ditolak dan Ha diterima. Dengan demikian dapat disimpulkan bahwa terdapat pengaruh yang signifikan motivasi belajar mahasiswa pada kelompok dengan metode resitasi sebelum dan sesudah diberikan perlakuan. 
Hipotesis pertama yang diajukan dalam penelitian ini adalah :

"Terdapat perbedaan motivasi belajar mahasiswa di FKIP Universitas Riau Kepulauan Batam antara kelompok yang diberi metode ceramah plus dan kelompok yang diberi metode resitasi”

Pengujian hipotesis ini ini dilakukan dengan teknik analisis data mengunakan Wilcoxon Signed Rangk Test melalui SPSS statistics versi 20 for windows. Berdasarkan hal tersebut didapat hasil perhitungan seperti yang terangkum pada tabel di bawah ini. Dapat kita lihat pada tabel di bawah ini:

Tabel 9. Hasil Analisis Wilcoxon Signed Rangk Test Perbedaan Motivasi Belajar Mahasiswa antara Kelompok Ceramah Plus dengan Metode Resitasi

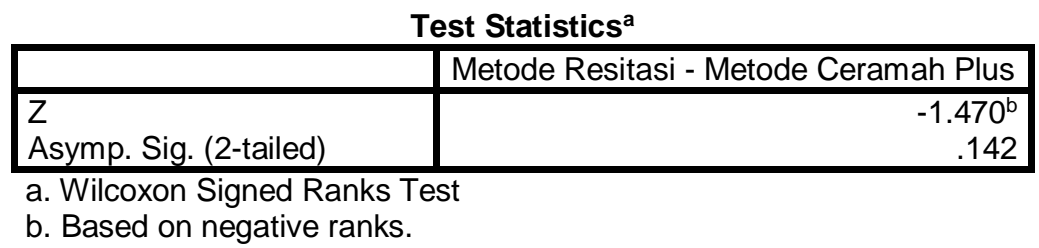

Berdasarkan tabel di atas dapat dilihat bahwa angka probabilitas Sig. (2-tailed) motivasi belajar mahasiswa pada kelompok dengan metode ceramah plus dan kelompok dengan metode resitasi adalah 0,142 atau probabilitas di atas alpha $(0,000<0,05)$. Dari hasil tersebut maka Ho diterima dan Ha ditolak. Dengan demikian dapat disimpulkan bahwa tidak terdapat pengaruh yang signifikan motivasi belajar mahasiswa pada kelompok dengan metode ceramah plus dengan motivasi belajar mahasiswa pada kelompok dengan metode resitasi.

\section{Pembahasan}

Berdasarkan hasil penelitian diketahui pada kelompok metode ceramah plus pada saat pretest dan posttest mengalami perbedaan. Pada saat pretest, motivasi belajar mahasiswa berada pada kategori sedang dan tinggi dengan skor total 601 dan nilai rata-rata 40,07. Sedang pada posttest terjadi peningkatan dengan skor total yaitu 890 dengan nilai rata-rata 59,33. Berdasarkan hasil penelitian diketahui pada kelompok metode resitasi pada saat pretest dan posttest mengalami perbedaan. Pada saat pretest, motivasi belajar mahasiswa berada pada kategori sedang dan tinggi dengan skor total 601 dan nilai rata-rata 40,07. Sedang pada posttest terjadi peningkatan dengan skor total yaitu 934 dengan nilai rata-rata 62,27. Berdasarkan hasil penelitian diketahui pada kelompok metode ceramah plus dan kelompok metode resitasi tidak mengalami perbedaan. Hal ini terlihat dari hasil taraf signifikansi di atas >0,005 yaitu sebesar 0,142 dengan nilai $\mathrm{Z}$ sebesar 1,470 .

Berdasarkan hasil penelitian tersebut dapat dilihat pengaruh yang signifikan dari perlakuan yang diberikan yaitu dengan metode ceramah plus terhadap motivasi belajar dan pengaruh 
signifikan dari perlakuan yang diberikan yaitu dengan metode resitasi terhadap motivasi belajar. Menurut Frandsen (dalam Sardiman, 2012) ada beberapa aspek yang memotivasi belajar seseorang dan salah satunya adalah adanya keinginan untuk mendapatkan rasa aman bila menguasai pelajaran. Apabila seseorang menguasai pelajaran dengan baik, maka orang tersebut tidak akan merasa khawatir bila menghadapi ujian, pertanyaan-pertanyaan dari guru dan lain-lain karena merasa yakin akan dapat menghadapinya dengan baik. Hal inilah yang menimbulkan rasa aman pada individu. Menurut Darsono (dalam Dwi, 2005) mengemukakan faktor yang mempengaruhi motivasi belajar unsur-unsur dinamis dalam belajar. Unsur-unsur dinamis dalam belajar adalah unsur-unsur yang keberadaannya dalam proses belajar tidak stabil, kadang-kadang kuat, kadang-kadang lemah dan bahkan hilang sama sekali, khususnya kondisi-kondisi yang sifatnya kondisional. Misalnya: gairah belajar.

\section{KESIMPULAN}

Berdasarkan hasil pengujian hipotesis dan pembahasan maka dapat ditarik beberapa kesimpulan dari penelitian ini, yaitu:

1. Terdapat peningkatan motivasi belajar yang cukup signifikan pada kelompok metode ceramah plus. Terbukti dengan banyaknya siswa yang memiliki motivasi belajar pada kategori sedang dan tinggi.

2. Terdapat peningkatan motivasi belajar yang cukup signifikan pada kelompok metode resitasi. Terbukti dengan banyaknya siswa yang memiliki motivasi belajar pada kategori sedang dan tinggi.

3. Tidak terdapat perbedaan yang signifikan terhadap motivasi belajar antara kelompok dengan metode ceramah plus dan kelompok dengan metode resitasi

\section{SARAN}

Adapun hal-hal yang dapat meningkatkan motivasi belajar mahasiswa antara lain :

\section{Mahasiswa}

Mahasiswa secara pribadi harus dapat mendorong motivasinya dalam belajar dan tidak mengantungkan diri pada metode pengajaran dosen. Hal ini dapat tercapai apabila mahasiswa memiliki kesadaran akan pentingnya belajar dan menuntut ilmu, sadar akan kewajiban sebagai mahasiswa, jika hal ini sudah ada dalam diri mahasiswa maka motivasi belajar akan terbentuk secara tidak langsung.

\section{Dosen}


Pendidik disarankan untuk selalu membantu mahasiswa untuk dapat meningkatkan motivasi belajarnya misalnya disaat proses belajar mengajar untuk dapat memilih metode pengajaran yang tidak membosankan dan sesuai dengan kebutuhan mahasiswa.

\section{DAFTAR PUSTAKA}

Asep Kusman. (2013). Kebijakan Penerapan Metode Resitasi Dalam Memanfaatkan Informasi Teknologi (IT) Sebagai Wujud Pengembangan Manajemen Pembelajaran Di Akmil. Universitas Negeri Semarang.

Saifuddin Azwar. (2013). Metode penelitian. Yogyakarta: Pustaka Belajar Offset.

Sugiyono. (2012). Statistik nonparametris untuk penelitian. Bandung: Alfabeta.

Sugiyono. (2013). Metode penelitian kuantitatif, kualitatif, dan R\&D. Bandung: Alfabeta.

Sugiyono. (2013). Statistika untuk penelitian. Bandung: Alfabeta.

Suharsimi Arikunto. (2013) Prosedur penelitian suatu pendekatan praktek. Jakarta: Rineka Cipta http://re-searchengines.com/art05-65.html diakses tanggal 13 September 2016 